by first distilling the chloroform under ordinary pressure and then distilling the isobutylalcohol under diminished pressure. While doing so bumping will never occur.

Mr. Charles E. CASPari :-With reference to these methods for the isolation of morphine from opium. The lime method does not yield all the morphine which is present in the opium. While it may be all right for comparative purposes, it does not give absolute knowledge of the actual amount of morphine which is present, either in opium, or opium preparations, which ever may be under examination.

I have had some experience with the method of shaking out with chloroform and alcohol. a modification of Dr. Engelhardt's method, as presented here, and I have found it to yield imnediate and certain results, and I have been very much pleased with it. I have used it particularly on tablets,-morphine mixed with other ingredients-and found that it was very satisfactory.

From my knowledge of the methods, I would say that I like the shaking-out method best. It is the simplest, and quickest, and as far as I can determine, the most accurate.

\title{
MICROSCOPY OF CINCHONA BARKS AND ADLLLTERANTS.
}

\author{
C. W. Ballard, M. A., PH. C., PhaR. D.
}

The question of the identity, both macroscopic and microscopic of the various species and varieties of cinchona, has been one of great importance for many years. The difficulties in the way of proper identification, are increased greatly, by the necessary admission of many hybrids of the official species. Of course, the drug is to great extent sold upon assay, but this does not relieve the pharmacognosist of the task of deciding, whether a sample submitted, is official or recognized, as there is always the possibility of the addition of non-official barks to a lot of genuine, and the more likely is such addition, when the drug is in powdered form. The chemistry of cinchona has been treated at great length in the proceedings of this Association, and, likewise, several papers have been submitted upon the macroscopic or gross appearance and structure of the drug, but, in a search of the publications, I fail to find much reference to the microscopy.

The results, in many cases, are not quite as definite and satisfactory as I would desire, and this lack of absolute uniformity, is undoubtedly due to hybridization in cultivation. An excellent article upon the subject of cinchona is given by Vogl, in his text book on Pharmacognosy (German), but this is not accessible to all, as I do not know of an English translation of the work. For this reason, I append a useful classification of the histological characteristics of the various cinchonas taken from this text book. (Dr. A. Vogl, "Pharmacognosie," Carl Gerold's Sohn, Vienna, 1892.)

Macroscopic characteristics are treated at length by so many authorities that no reference will be made to them, excepting, if necessary, to more fully explain microscopic structure. I append a list of the literature available at the library of Columbia University College of Pharmacy upon the subject. A further list, and one which is complete up to the date of publication, is given in the English translation of Fluckiger's "Cinchona Barks," by F. B. Power (Blakiston, 1884). In this connection, I would make special mention of a folio volume in French, “Historie Naturelle des Quinquinas," M. H. A. Weddell, 1849, which contains excellent illustrations in natural color of many specimens. 
Cinchona Cailisaya and Cinchona Ledgeriana:-As these two species are found to comply with the official requirements as regards alkaloidal content, we may for purposes of comparison consider them as standard. For descriptions and illustrations of histological structure, we cannot do better than consult the material given under the head of Cinchona in the following references: Vogl. "Pharmacognosie"; Vogl, "Atlas sur Pharmacognosie"; Moeller, "Pharmacognosticher Atlas."

As will be ascertained by the above references, the histological elements found in powdered Calisaya or Ledgeriana barks are: cork, flat, thin-walled, with brown contents; parenchyma, thin-walled, containing starch and crypto-crystals; characteristic bast fibers; medullary ray tissue; thin-walled tissue of laticiferous ducts; tissues of the lichens attached to the bark.

Cross sections of barks of both these species, exhibit the following picture. An outer corky layer, brown in color, composed of flat quadrangular cells, the outer portions being very thick, and not being as distinct to view as the inner part. Below the cork is the parenchyma of the middle bark containing numerous bast fibers either isolated from one another or in groups of two to five. In this parenchyma will be found cells containing crypto-crystals and a few containing small starch grains. The laticiferous ducts in this region are circular, thin-walled and rather larger than the parenchyma cells. Coming to the inner bark, we notice the medullary rays made up of flat rectangular cells with long axis toward the cork, these being usually one to three cells in width. Between them are located the bast fibers, for the most part in groups of four or more. The parenchyma of this region. is composed of small cells, a few of which contain starch. By some authorities, stone cells are said to occur in the middle portion of these barks, but they were not found in the specimens examined.

Cinchona Ledgeriana possesses a larger quantity of bast fbers than Calisaya. The bark parenchyma also contains starch of moderate size, whereas calisaya parenchyma contains very little starch, and that which is present is very small. In many of the bast fibers of Ledgeriana, the ends are double pointed, whereas all other species have single pointed ends.

The indentations or pores of the inner wall of the bast fibers of Calisaya and Ledgeriana are somewhat deeper than those of Succirubra, but are not as broad. The cavities of the fibers in Calisaya and Succirubra are about the same size, but those of Ledgeriana are generally much larger. The bast fibers of all three, are striated in a direction parallel to the length of the fiber, but the striations of Ledgeriana, are fewer and coarser than in the other two. In many instances in Calisaya, the pore begins at the cavity as a single narrow opening, but, upon penetrating the wall of the fiber for a short distance, it separates or branches out into two parts. While there are double pores in Succirubra, the opening from the cavity is very wide, usually wider than the pore itself.

Cinchona Succirubra:-In a cross-section of succirubra bark, we have the outer layer of cork similar to that in the preceding species. The middle bark consists of thin-walled parenchyma cells, containing much starch and many cryptocrystals, and within this parenchyma are laticiferous ducts which are very large. Very few bast fibers are present in this region. In the inner bark are found the medullary rays and bast fibers, the latter usually in groups running parallel to 
the rays. The rays are usually three cells in width and are almost parallel to one another.

In the powder, the bast fibers are the most prominent element, being more numerous and rather more slender in this variety than in Calisaya. The fibers are striated, but the striations are coarser than Calisaya. Three types of fiber were noted: those with both ends sharp-pointed; those with one end square and the other pointed; the third with one end square, the other being square excepting for a projecting point, similar to the peculiar fibers of Ledgeriana except that those of the latter have a double point. The variety with one narrow projecting point predominate. The indentations of the inner wall, are wider but not as deep
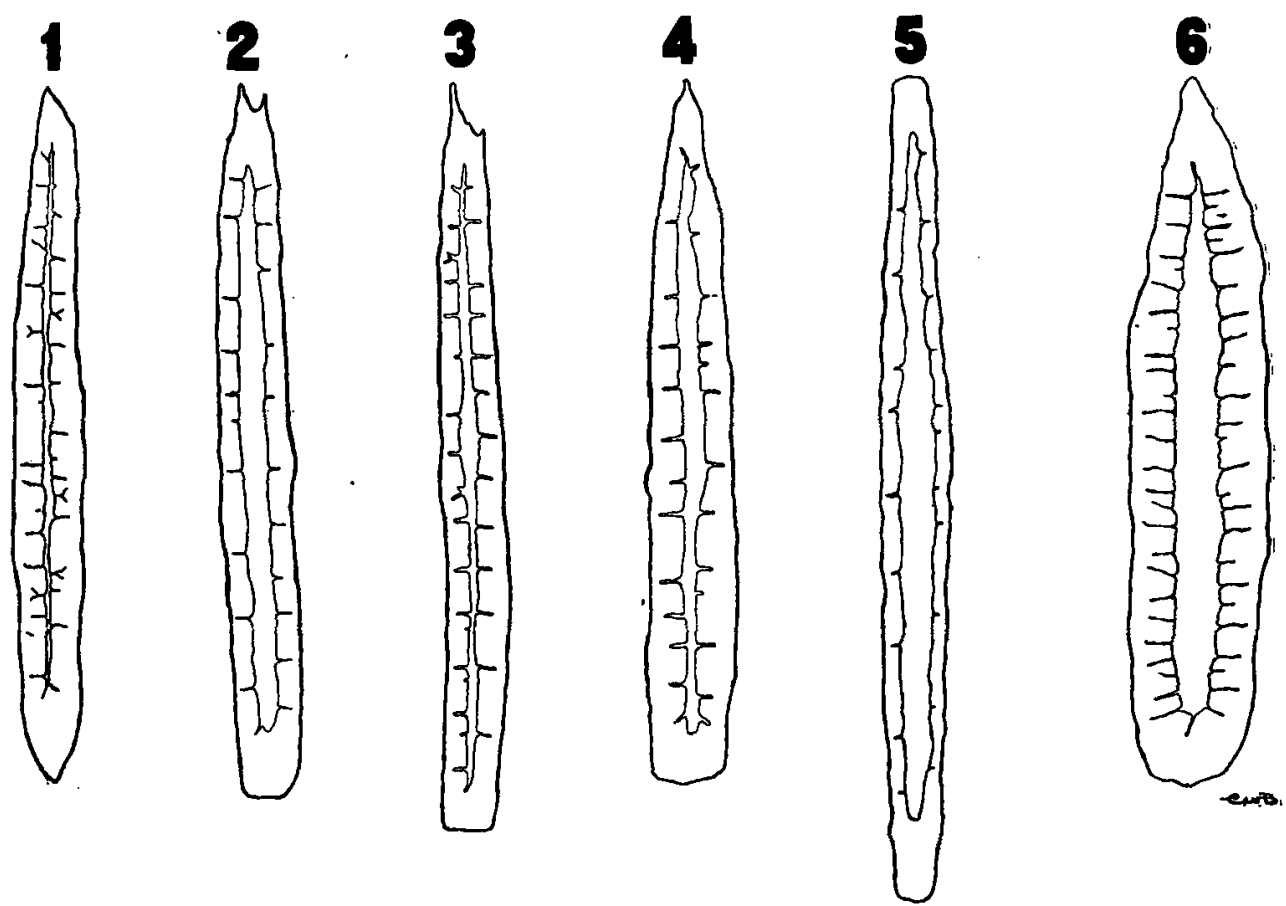

COMPARISON OF TYPICAL FIBERS.

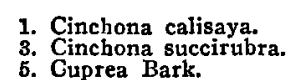

2. Cinchona ledgeriana.

4. Cinchona officinalis.

5. Cuprea Bark.

6. Maracaibo Bark.

as those of Calisaya and Ledgeriana. There are, in many fibers, double pores: which have wide openings from the cavity, thus distinguishing them from Calisaya.

One fact noted, was that the parenchyma of this variety, is for the most part filled with starch; also the total amount of starch in the field is considerably greater than in Calisaya or Ledgeriana. This feature, although not an altogether certain and definite one, may furnish a clue to the derivation of a sample.

One other element which may be found in this variety and which may be rather confusing at times is lichen tissue.

CinchoNA OFficinalis (Loxa Bark):-The transverse sections of specimens of this variety exhibit an outer corky layer, to which lichens may be adherent. 
The cork cells are of the usual type, rectangular, small, thin-walled and brown. Below the cork is the parenchyma of the middle bark containing a few small laticiferous ducts. Bast fibers, if present in this region, are very few in number. In the inner bark, occur the medullary rays composed of large rectangular cells, each ray running parallel with the others and being somewhat wider as they approach the middle bark. These rays are two cells wide in the inner bark, but expand to three or four cells in width, upon reaching the middle region of the specimen. Between the rays occur bast fibers, singly or in groups of two to four, and have very small cavities. The remaining space between the rays, is filled in with the bark parenchyma interspersed with the sieve cells.

The powder of $\mathrm{C}$. officinalis contains the usual elements found in the true cinchonas. The fibers and parenchyma are of about equal prominence. The structure of the cork cells is easily seen, but the fibers are not as numerous as in the other official varieties. In a majority of cases, they are flattened at one end and sharp pointed at the other, although a few are pointed at both ends. The cavity is very narrow and the indentations or border pores, which are in all cases single, extend to the outer margin of the fiber. Striations are found running parallel to the long axis of the fiber. The parenchyma in the powder, is usually in very good condition and is always more or less filled with small starch grains and small crypto-crystals. Medullary rays are large and easily seen in the powder, the individual cells being rectangular and occurring in groups attached to the fibers.

CUPREA BARK (Remijia pedunculata):-This substitute for the genuine cinchonas, is not entirely worthless, although of an entirely different genus. It contains some cinchona alkaloids, and is therefore more likely to escape detection during assay processes.

The cross-section of this bark shows a few layers of thick-walled brown cork cells at the outer margin. The middle bark contains groups of characteristic, yellow, stone cells, large and moderately thin-walled, usually filled with starch or reddish-brown contents. Laticiferous ducts are said to occur in some specimens, but I did not observe them in two out of three specimens examined. The inner bark contains the medullary rays and groups of densely-packed, small, but thinwalled bast fibers. The rays are very irregular as regards direction and width. In many cases they are wavy and not parallel with each other or extending through the bark at right angles to the cork, as in genuine barks. The individual cells of the rays are rather long, and either rectangular or circular, being filled with reddish contents, making them much darker than the surrounding cells. In many specimens, the rays broaden out upon reaching the middle bark, as in C. officinalis and merge almost imperceptibly with the parenchyma of this region. In width, the rays vary from one to four cells. The bark parenchyma and sievetissue of the inner bark, is almost entirely displaced by the densely-packed bast fibers.

The powder of this variety, is characterized by numerous stone cells and bast fibers, square or rounded at the ends, and occurring in groups arranged end to end. Their walls are very thin and the cavities of these fibers are large, but the inner walls are not, markedly, indented as in genuine species. The stone cells 

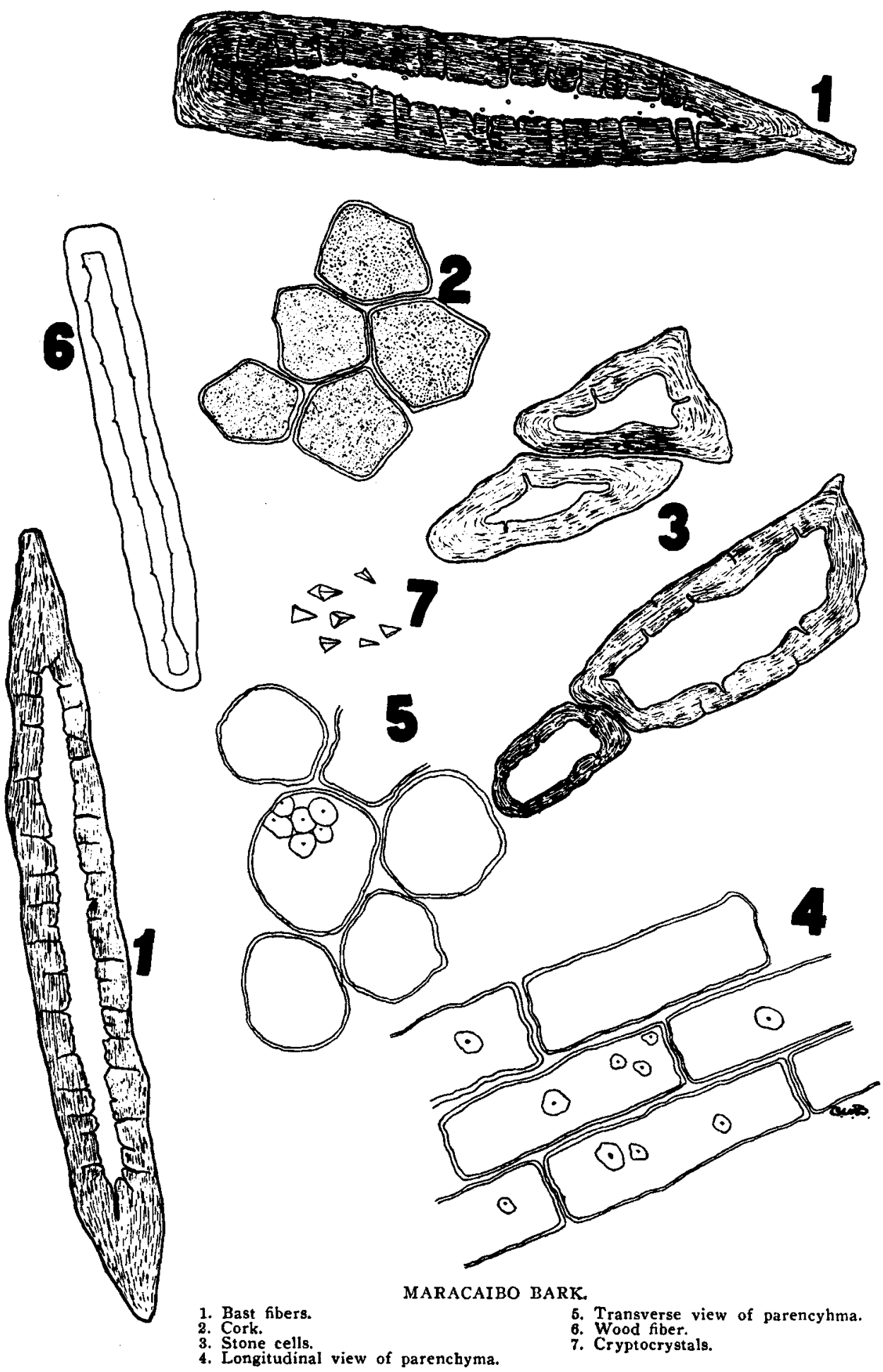
are square, or polygonal, with a few circular shape, finely striated with deeplyindented inner margin. Some are filled with starch, others with reddish-brown contents. The medullary ray tissue, is very prominent in the powder both in longitudinal and transverse section. It is adherent to the short fibers and the bark parenchyma. Many of the parenchyma cells are filled with starch. Cryptocrystals are present in this powder, but are less numerous and smaller than in the genuine barks.

The peculiar fibers render this adulterant very easy of detection, and the stone cells render such finding certain.

MARACAibo BARK:-Maracaibo bark has been used very recently as an adulterant of the yellow cinchonas, especially that sent to market in chip form. It is not, in any sense, a purely theoretical adulterant, or one which might be thought to be of use for nefarious practice, for several samples of cinchona have consisted in part, and in some cases the greater part, of this spurious bark. Its botanical origin seems to be rather obscure, and it is not mentioned under the above commercial name in most scientific works.

The transverse section of most samples, shows very little corky tissue, as this peels away very easily. The middle region of the bark, contains many groups of large thick-walled yellow fibers and few yellow stone cells. Laticiferous ducts are also present. The parenchyma is of small irregular brown thin-walled cells. The inner bark consists of very small, and dark-colored medullary rays, usually two cells in width; the rows being comparatively far apart as compared with all other barks. Between the rays, we find groups of large, yellow bast fibers and rather large quantities of small, irregular thin-walled parenchyma. The fibers are wider than any other related bark, but are not as numerous as in cuprea.

In powdered form, the bast fibers are, as in the true cinchonas, most prominent. They are considerably wider than fibers of the true species, and are very coarsely marked with striations running parallel to the outer margin. Both ends of the fibers are sharp-pointed. The cavity is very large, and the indentations extend almost completely to the outer margin of the fiber. The wood fibers which are present, are about as long as the bast, but are very slender, thin-walled, with square ends and filled with reddish-brown contents. The stone cells are large, triangular or rectangular in shape, yellow in color, with thick walls. The cavities of these stone cells are marked by many indentations or pores and they may be filled with starch. Numerous well defined crypto-crystals are present, many of them being very large.

RENEWED BARK:-A transverse section was prepared from a sample of the socalled renewed bark, and examined to discover any changes brought about by the renewing-process. This renewing, or stripping, of the outer bark from the tree, and the covering of the bared places, with moss or material to prevent access of light, is said to yield a bark much higher in alkaloid than the ordinary.

In renewed bark, the thick, brown, corky layer is of course absent, although a small amount may remain. In the region which, in an untreated bark, would correspond to the middle bark, we find at the outer edge several rows of flat. almost perfectly rectangular cells, resembling cork but not deeply-colored; they representing secondary cork formation. Below this secondary cork, is a wide 

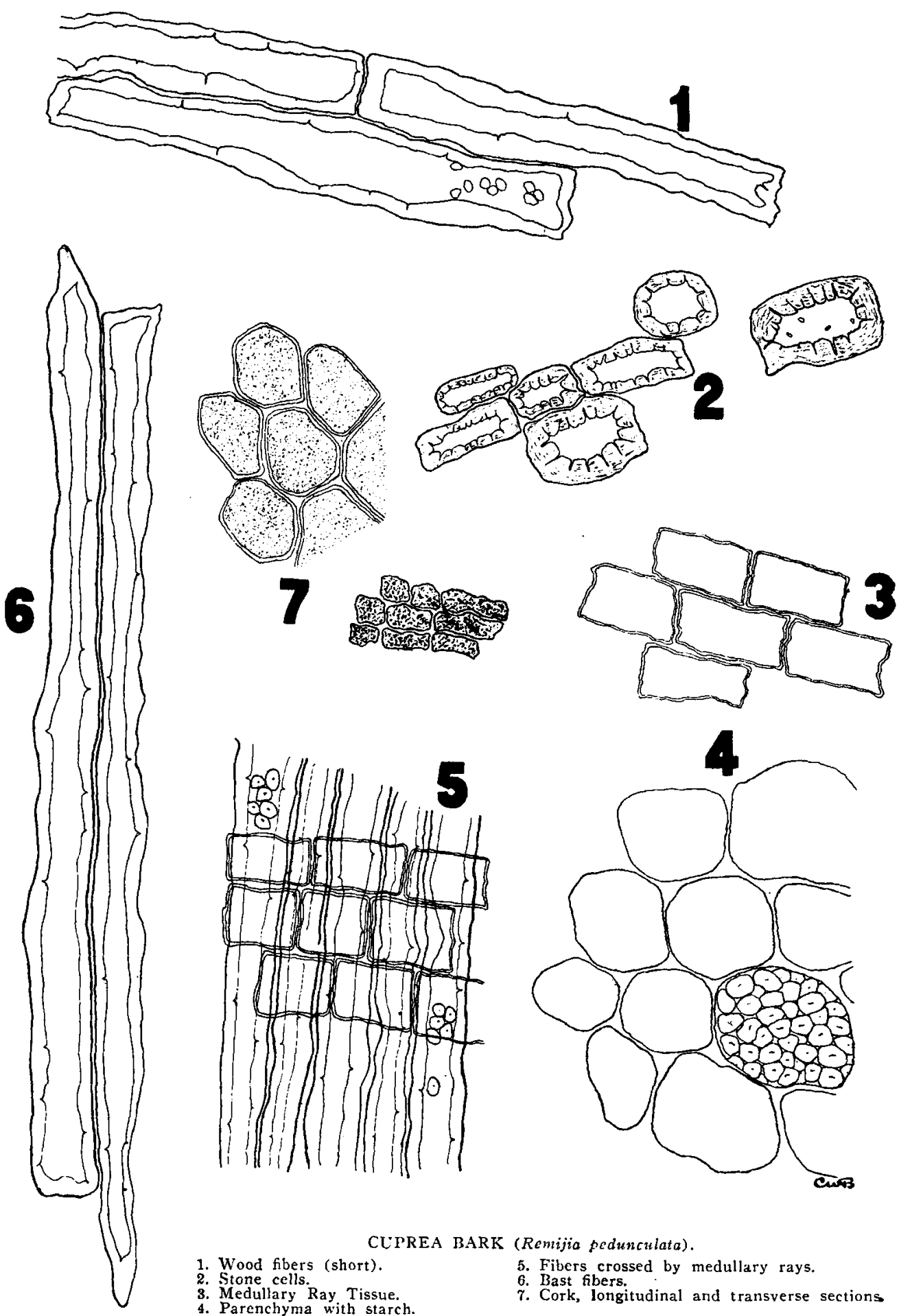

CLPREA BARK (Remijia pedunculata).

1. Wood fibers (short).

2. Stone cells.

3. Medullary Ray Tissue.

4. Parenchyma with starch.
5. Fibers crossed by medullary rays.

6. Bast fibers.

7. Cork, longitudinal and transverse sections 
zone of circular parenchyma cells, in which remains of the previously existing medullary rays may sometimes be seen. A few small laticiferous ducts are also present in this region, but bast fibers are entirely wanting. In the region corresponding to the inner bark, are the true medullary rays, two or three cells in width, and of large but narrow cells. The bast fibers in this region, are very numerous with thick walls, small cavity, and, in a majority of instances, a rectangular outline on transverse section. Small amounts of bark parenchyma and sieve tissue also occur between the rays.

In the powder of renewed bark, the most prominent elements are the fibers and the masses of secondary cork.

MEASUREMENTS OF FIBERS IN VARIETIES DISCUSSED.

\begin{tabular}{|c|c|c|c|c|}
\hline & & & & $\begin{array}{l}\text { RELATION } \\
\text { OF LENGTH }\end{array}$ \\
\hline & SMALL & AVERAGE & LARGE & TO WIDTH \\
\hline Calisaya .. & $0.414 \times 0.054 \mathrm{~mm}$ & $0.659 \times 0.061 \mathrm{~mm}$ & $0.828 \times 0.090 \mathrm{~mm}$ & $10-1$ \\
\hline Ledgeriana & $0.495 \times 0.045 \mathrm{~mm}$. & $0.675 \times 0.059 \mathrm{~mm}$. & $0.990 \times 0.081 \mathrm{~mm}$ & $11-1$ \\
\hline Succirubra & $0.540 \times 0.045 \mathrm{~mm}$ & $0.739 \times 0.057 \mathrm{~mm}$ & $0.828 \times 0.072 \mathrm{~mm}$ & $13-1$ \\
\hline C. officinalis ...... & $0.250 \times 0.025 \mathrm{~mm}$. & $0.399 \times 0.038 \mathrm{~mm}$. & $0.575 \times 0.050 \mathrm{~mm}$. & $10-1$ \\
\hline Cuprea (Remijia) .. & $0.160 \times 0.015 \mathrm{~mm}$. & $0.267 \times 0.018 \mathrm{~mm}$. & $0.423 \times 0.020 \mathrm{~mm}$. & $15-1$ \\
\hline Maracaibo ......... & $0.612 \times 0.063 \mathrm{~mm}$ & $0.783 \times 0.094 \mathrm{~mm}$. & $1.170 \times 0.135 \mathrm{~mm}$ & $8-1$ \\
\hline
\end{tabular}

SUMMARY OF THE IMPORTANT CINCHONA BARKS ACCOIDING TO HISTOLOGICAL CHARACTERISTICS.

A. Barks with cork prcsent.

(After Dr. A. Vogl.)

I. Bast fibers prominent-radially and tangentially arranged.

a. Stone cells present in middle bark and outer portions of inner, bark.

Stone cclls mostly in middle bark-laticiferous ducts absent.

Wood cells (stabsellen) in bast region $=C$. lancifolia.

Wood cells (stabzellen) none $=C$. lucumaefolia.

Stone cells not prominent in middle bark.

Bast bundles in very perfect isolated groups $=C$. macrocaly.

Bast bundles toward the last not arranged in series $=C$. Palton.

b. Stone cells absent or scattered in middle bark or outer portion of inner bark.

Bast fibers very thick $(90-250 \mathrm{~mm}$.)-Laticiferous ducts wanting or at hes' very narrow.

Wood cells present $=C$. Pahudiana.

Wood cells absent $=C$. pubescens.

Bast fibers moderately thick $=C$. obtusifolia.

Bast fibers thin-laticiferous ducts wanting or narrow $=C$. officinalis.

II. Bast fibers arranged in radial series or rows.

a. Laticiferous ducts absent.

Bast fibers thin or equally thick throughout the section-in interrupted radia? rows $=C$. Pitayensis.

Bast fibers unequally thick-the outer ones thinnest.

Mcdullary rays of large cells-wood cells present.

Middle bark without stone cclls or with single stone cells= C. cordifolia.

Middle bark with many stone cells $=C$. Lancifolia.

Medullary rays of small cells-as a rule no wood cells $=C$. lancifolia

b. Laticiferous ducts present.

Midrlle hark containing numerous stone cells.

Bast fibers thin or very thin,

partly in interrupted rays-wood tibers prosent $=C$. scrobiculata.

In interrupted rays-wood fibers absent $=C$. ovata.

Bast fibers moderately thick - wide laticiferous ducts in middle bark-very many stone cclls-wood cells in bast region $=C$. pertiviana.

Middle bark containing scattered stone cells or the latter absent.

Narrow laticiferous ducts.

Bast fibers moderately thick. the onter ones thinner.

In regular zones-bast region soft $=C$. officinalis.

Without regular zones=C. heterophyila.

Bast fibers thick the outer ones thicker $=C$. ticujensis. 
Wide laticiferous ducts.

Bast fibers very thin in interrupted radial series,

With "KOH," sections give blood-red reaction-bast fbers orange color $=C$. succirubra.

With "KOH," thin sections give yellow or reddish-brown reactionfibers yellow $=C$. cal. or ledger.

B. Barks in which cork is absent.

a. Bast fibers in tangential bundles-moderately thick, bark very soft, brittle and tibrous $=C$. lucumaefolia.

b. Bast fibers expanding in outward direction - many in radial series thin or very thinfor the largest part in uninterrupted lines.

In double lines-cork still present-wide laticiferous ducts and numerous stone cells, fracture rough showing protruding ends of fibers $=C$. scrobiculata.

In single lines-stone cells wanting-short fracture $=C$. australis.

Moderately thick in interrupted single lines.

Bast fibers equally thickened-medullary rays extending directly outwardsharp fracture $=C$. calisaya.

Bast fibers not equally thickened.

Large celled medullary rays $=C$. officinalis.

Small celled medullary rays $=C$. micrantha.

Literature which may be consulted upon the subject of Cinchona.

"Historie Naturelle des Quinquinas," M. H. A. Weddell, 1849.

"Pharmacognosie," Dr. A. Vogl.

"Atlas zur Pharmacognosie," Dr. A. Vogl.

"The Cinchona Barks," Dr. E. A. Fluckiger, translation by F. B. Power.

"National Standard Dispensatory," 6th Ed., Hare, Caspari, Rusby.

"United States Dispensatory," 18th Ed., Wood, Remington, Sadtler.

Columbia University College of Pharmacy.

\section{ASSAY OF HYDRASTIS AND FLUIDEXTRACT OF HYDRASTIS.}

H. W. JONES.

The abstracts of proposed changes to be made in the forthcoming revision of the U. S. P. have been greeted with great interest and none perhaps more so than those dealing with the alkaloidal assays. (Jour. A. Ph. A., 1914-7, pp. 984-997.) Among the various assay processes of the U. S. P. (VIII), there was assuredly none more in need of revision than that of Fluidextract of Hydrastis, and the proposed change in the assay of this preparation will no doubt meet with general approval.

Puckner (Pharm. Rev., 1908, 26, pp. 132-137) called attention to the considerable error incident to the use of the eighth revision method, and pointed out the source of error, namely, the carrying down of hydrastine by the berberine hydriodide precipitate with the result that the $50 \mathrm{cc}$. aliquot part taken did not fully represent $5 \mathrm{cc}$. of the fluidextract, but gave too low a result. He proposed an excellent modification of the method, although apparently this modification has not met with general approval.

Eldred and Pence (Proc. A. Ph. A., 1908, pp. 836-838) also remarked on the low results obtained through the use of the eighth revision method, and also gave results obtained by a method used in their practice.

Dichgans, working under Prof. Tschirch, in a comparative examination of the assay processes of the different Pharmacopoias (Apoth. Ztg., 29, 46, pp. 516-519), 